\title{
The Analysis of Modern Information and Fire Conflict Distinctive Features
}

\author{
Gennady V. Zibrov \\ Military Training and Research Center of the Air Force \\ «Air Force Academy ft. Professor N.E. Zhukovsky and Y.A. Gagarin» \\ 54 a Starykh Bol'shevikov Str., Voronezh, 394064, Russia
}

Received 01.09.2015, received in revised form 19.01.2016, accepted 01.03.2016

The article dwells upon the role of information superiority in achieving the geopolitical goals. The stages of states and their allies' opposition are considered. The importance of overtaking the opposing force in reconnaissance is explained. The military-system analysis of initial conflict opposition characterizing the high degree of tension and further development of this opposition, main tendencies of intelligence gathering systems are stated.

Keywords: information superiority, strict conflict.

\section{Анализ особенностей информационно-огневых конфликтов современности}

Г.В. Зибров

ВУНЦ ВВС «ВВА им. проф. Н.Е. Жуковского и Ю.А. Гагарина» Россия, 371600, Воронеж, ул. Старых Больиевиков, $54 \mathrm{~A}$

В статье показана роль информационного превосходства в достижении геополитических иелей, рассмотрены этапы противостояния государств и их коалиций. Обоснована важность опережения противоборствующей стороны в выполнении разведывательных задач. На основе военно-системного анализа начального конфликтного противостояния, характеризующего высшую степень напряженности и дальнейшего развития этого противоборства, определены основные направления совершенствования систем разведки.

Ключевые слова: информационное превосходство, строгий конфликт.

Information superiority of the Russian Federation Armed Forces (RF AF) over a potential opponent is considered as one of fundamental factors in the achieving of the final goal - defeat of the

C) Siberian Federal University. All rights reserved

* Corresponding author E-mail address: zibrov77@inbox.ru 
opponent's armed forces or refusal of their military-political administration to further implement their plans on the beneficial for the AF of Russian Federation terms. Each of the branches and arms of the $\mathrm{RF}$ AF in accordance with current plans plays the most active role in accomplishing certain tasks to achieve the information superiority over the opposing force. The process of gaining the information superiority itself is thoroughly enough connected with the stages of opposition of the states (allies), where the most important ones are [1,2]:

1. Origin of opposition (resulting from economic, territorial, ideological, disagreements in the military sphere and actions of the contestants).

2. Forming the alliance of like-minded states and denial of making similar alliances to the opposing state (or taking measures to destroy the already formed alliance of states).

3. Intelligence intensification (in the political, economic, military, scientific area) of the opposing state and its satellites.

4. Preparation and persistent influence on the world community by representing the opposing state as an aggressor posing a real threat to the world.

5. Gaining the approval from the UN to begin the military aggression against the opposing state (opposing coalitions of states) or preventing the opposing state from gaining such an approval.

6. Hampering (dissolution of) the activity of state and military administration on the whole territory of the opposing state (alliance of states).

7. Conducting information and psychological offensive operations against the opposing states and their Armed Forces taking into account different layers of population, political and religious patterns, level of media and telecommunications development.

8. Fire damage and electronic destruction of state and military control systems (notification systems).

9. Destruction of air defense capabilities as well as the means of counter strike and launch under attack, including those that pose the threat to friendly information assets.

10. Defeat of the opposing states' Armed Forces and forcing the military and political leaders to surrender.

11. Representation of the convincing information to world community that prove the conducted military operations were extremely needed and timely. Forming and presenting the base of evidence.

The struggle for information superiority will be conducted within the framework of specific operations and actions, where information-technical and information disseminating facilities of different hierarchical levels will be applied [1,2].

The struggle for information superiority is a complex information conflict, in which the opponents, besides the reconnaissance activities, will engage the objectives to hamper or impede their application, while taking measures to ensure unimpeded performance of friendly information assets.

Information confrontation is the information contest which intends to provide a full-scale destructive effect on information, information systems and information infrastructure of the opposing force and simultaneous protection of friendly information, information systems and information infrastructure from the similar effect [3].

Consequently, the information confrontation may involve offensive and defensive actions in the information conflict. Generally speaking, the information confrontation can be regarded as a set of 
components, where the information conflict (as part of Information Warfare) and the information support are considered to be the primary elements.

The modern stage of the information support development is characterized by dramatic changes in maintenance of functional actions, structure of the information support system as well as methods (forms) of information support of the Armed Forces during the implementation of different tasks in war and peace.

One of the main components of the information support is the reconnaissance system, which is primarily developed to form the necessary potential in the information confrontation. The latter is being constantly improved, and special emphasis is laid on its accuracy, authenticity and operational efficiency; overtaking the opposing side in this aspect is crucial. To gain this objective the joint ground, air and spatial reconnaissance units establish multi-fold, and at the same time interrelated centers to collect, process and disseminate information. Such centers provide necessary intelligence data to the military leaders of different levels, and provide effective operation of the airborne reconnaissance and fire weapons systems.

Maintaining the superiority in the information support requires constant and comprehensive consideration of reconnaissance capabilities of the developed states and generation of reasonable ways of reconnaissance systems further development. To date the US leaders complete the second fundamental modernization of collection, processing and dissemination information system. Improvements are being made to increase operational efficiency, authenticity, and accuracy of the intelligence information. To gain this objective the joint structure of the operating systems and unified software is developed, the procedures of data submission and logging are utilized. It, in turn, allowed for critical advance in automatic performance and eliminating the negative impact of subjectivity in the intelligence data assessment. The USA military leaders believe that the complete deployment of the perspective information support systems will be in agreement with the main regulations of the Network-centric Warfare. Within the framework of the reconnaissance systems upgrading the procedure of intelligence data analysis is taking place. It includes:

- development and application of fast-acting algorithms of processing signals obtained from different sensors, secondary and tertiary information processing through unified mathematical approach and absolute languages;

- development and application of integrated formats of data submission and logging;

- tailoring the existent collection, processing and dissemination information systems to the growing information network space and to combat capabilities in the consolidated information area;

- development of hi-tech means and methods of data submission to the consumer whenever it is need, displaying the zones of ambiguity;

- establishing the direct communications and intelligence transmission channels to send data immediately to the fire assets and Electronic Warfare means;

- providing the required level of co-operation through establishing the users' access to opticalelectronic, radiolocation, Electronic Support Measures and other types of data, as well as through the building-up a unified situational awareness;

- increase of data flow control effectiveness.

The advance in forms and methods of reconnaissance provides for [4 - 8] further combination and integration of all reconnaissance means into the consolidated system with the effective leadership 
techniques. It should be noted that the modern stage of development in the military reconnaissance system elements is characterized by distinctive conflict-system approach to their further perfection. Thus, special attention is paid to the systems of information support of battle actions of Russian Federation of the developed states to maintain national security at the necessary level.

In this connection, urgent development of the information support systems, both for the state and its Armed Forces, is becoming of primary importance. As a matter of experience, battle actions in the Persian Gulf, on the Balkans and lately in the Near East [2], there is a tendency in research plans and designers' work conducted by the developed states to upgrade reconnaissance technique. The distinctive feature of the plan is that scientific-technical reconnaissance units, founded here, accomplish the primary tasks to gain information about different states achievements in the area of upgrading reconnaissance, integrated technical monitoring, Electronic Counter-counter measures. Moreover, much attention is paid to the problems of forecasting and simulation of one's own Armed Forces information support capabilities in military conflicts of different nature and intensity. This proves the ambition of the developed states to achieve insured information superiority above potential opponents in any potential situations and on all stages of opposition (origin of conflict, beginning of conflict actions, intensification of tension, crisis, beginning of combat actions, renewal of neutral military relations (peace recovery)). It is well-proven [6], that rational behavior is a condition under which a party will join the information confrontation only if it is certain to achieve the information superiority. It is considered that the parte having lost the information confrontation will be long unable to amend this condition. The identical situation is expected in case of the armed conflict. The party joins the armed conflict only if there is information superiority over the opponent during the whole period of confrontation with the relatively equal munitions.

Lately there is a steady tendency of tailoring the conventional weapons and Electronic Warfare facilities and systems to solve the problems of the information confrontation, including the development of specific weaponry to use in information conflicts. At the heart of its design is:

- the most advanced information support systems;

- rapid highly-accurate delivery;

- operational highly-reliable integrated monitoring.

In spite of the above-mentioned, the achievement of information superiority will be also pursued through the use of conventional airborne highly-precision weaponry which is being upgraded and updated according to the following aspects:

- improvement of the precision-guided munitions' (PGM) features (increase of range, increase in the number of simultaneously hit targets, increase the effectiveness of target location and selection equipment;

- reduction of signatures level of PGM as well as of its delivery vehicles by means of reducing their electromagnetic radiation, application of passive guidance systems, reducing the effective radar cross-section of both PGM and its delivery vehicles in radar operation and optical range frequencies;

- reduction of dependence between efficient PGM guidance and natural and deliberate jamming effects by means of new principles of anti-jam protection techniques, integration of sensors performing in different spectral ranges with automated navigation systems, application of special algorithms of the desired signal processing; 
- integration of reconnaissance and engagement facilities, systems development to search for, control and destroy information objectives with PGM.

The ways to improve PGM according to the mentioned above aspects include [8-10]:

- wide use of multi-unit and multispectral optical sensors, modern element base for the digital signal processing, special types of sounding pulses (encoded signal, in particular);

- application of moving-target indicator cancellers and noise protection circuits on the basis of joint analysis of time-response and spatiospectral characteristics of the desired signals;

- increased structural selectiveness (through the development of the basic and alternative surveillance, aiming and targeting channels);

- computerization of search, location and identification;

- increase of the optical-electronic systems anti-jam capability due to space and time covering warning channels, which prevent unauthorized disclosure of powerful radiation sources;

- use of special principles and algorithms of signals reception based on amplitude-phase effects;

- use of the effective optical systems, designed on the basis of the latest technological achievements which provide high frequency and spatial selectivity.

The main feature of the new generation PGM, based on the information support system achievements, which has a profound value, is the system-level principle of complex neutralization of opponent's activities. The latter is achieved by means of consistent application both the means to increase the stealth and anti-jam capabilities and special countermeasures, denying the opponents counter operation. It ensures the effectiveness of the perspective information support systems and PGM guidance systems in case of potential opponents' interference into their performance, and, ultimately, creates favorable conditions to achieve the goal despite the hindrance of the opponent forces, which is the characteristic of conflict stability. The high conflict stability of the perspective information support systems, PGM in general and PGM control systems in particular distinguishes them from the radio electronic munitions legacy system [6].

The experience of weapons system application in local wars and armed conflicts [2] allows the following conclusions:

1. Each opposing party rapidly develops its weapons system, striving to attain maximum results before combat actions begin (during peace-time and active information confrontation).

2. Any modern weapons system contains offensive and defensive subsystems. Each subsystem is multifunctional and used both for strikes and counter-strikes delivery.

3. The structure of the modern weapons system is flexible as the updated computer-aided control systems provide efficient structures under the changing conditions of confrontation.

Offensive weaponry update level is characterized by retaining C4I systems in operational mode (including all major defensive facilities) and counter capability to the multidimensional attack. The level of offensive weapons updating is characterized by the striking ground and aerospace systems capabilities so that the opposing party is unable to strike back.

Considering the bilateral antagonistic conflict, both opponents may be characterized by the level of weapons system development:

1. The party is not ready to deal with a massive strike, neither they are ready to deliver a massive strike $\left(\mathrm{C}_{1}\right)$. 
2. The party is ready to deal with a massive strike, but they are ready to deliver a massive strike $\left(\mathrm{C}_{2}\right)$.

3. The party is not ready to deal with a massive strike, but they are ready to deliver a launch under attack $\left(\mathrm{C}_{3}\right)$.

4. The party is not ready to deal with a massive strike, neither they are ready to deliver a preventive strike $\left(\mathrm{C}_{4}\right)$.

5. The party is ready to deal with a massive strike, and they are ready to deliver a launch under attack $\left(\mathrm{C}_{5}\right)$.

6. The party is ready to deal with a massive strike, and they are ready to deliver a preventive strike $\left(\mathrm{C}_{6}\right)$.

The defense readiness alert for a massive strike according to [7] is thought of as a friendly defense capability of more than $65 \%$ from the initial quantity with the certainty value of 0,99 under the conditions of the PGM massive strike simultaneous delivery to destroy the opposing force defense in depth. This index of defense effectiveness should be solely concerned with defense system capabilities without taking into consideration massive strike facilities of the opposing force at the moment of launch under attack and preventive strike delivery.

The state of opposing parties will be characterized by exhaustive events:

$$
C_{i} C_{j}, \bar{C}_{i} \bar{C}_{j}, \bar{C}_{i} C_{j}, C_{i} \bar{C}_{j}, i \in \overline{1, n}, j \in \overline{1, m}, i \neq j
$$

where $C_{i} C_{j}$ - is the system status, $i$ - the state number of the first party, $j$ - the state number of the second party.

The number of potential initial situations will be estimated by the equation $Q=C_{n, n}^{2}$. Here the following condition should be met:

$$
\begin{aligned}
& P\left(C_{1} C_{2}\right)+P\left(\bar{C}_{1} \bar{C}_{2}\right)+P\left(\bar{C}_{1} C_{2}\right)+P\left(C_{1} \bar{C}_{2}\right)+\ldots+ \\
+ & P\left(C_{n} C_{m}\right)+P\left(\bar{C}_{n} \bar{C}_{m}\right)+P\left(\bar{C}_{n} C_{m}\right)+P\left(C_{n} \bar{C}_{m}\right)=1
\end{aligned}
$$

where $\mathrm{P}\left(\mathrm{C}_{1} \mathrm{C}_{2}\right)$ is the probability that the event $\mathrm{C}_{1} \mathrm{C}_{2}$ took place.

Setting the time law $t$ the probability of gaining the victory for the opposing forces depends on the reconnaissance systems combination used by the opponents, let us introduce the following notation:

$$
P_{1}(t)=\left\{P_{a 1}(t), P_{a 2}(t), \ldots, P_{a k}(t)\right\} ; P_{2}(t)\left\{P_{b 1}(t), P_{b 2},(t), \ldots, P_{b k}(t)\right\}
$$

where $k=i x j$.

Setting the time of gaining superiority distribution, the superiority index of opposing forces ' $a$ ' and ' $b$ ' is the equation:

$$
\mu(t)=\frac{P_{1}(t)}{P_{2}(t)},
$$

which allows the conflict analysis by forming the state space trajectory.

It is obvious, that in every conflict the significance of reconnaissance systems performance is diverse, though in comparison with other subsystems it will be of primary importance which is proved by information support capabilities to solve two kinds of interrelated problems of massive strike(s) delivery and protection of friendly AF against massive strikes. If the conflict reference state is

$$
-337-
$$


characterized $Q_{i j}$, the information subsystem requirements are determined by the necessary primary index of party ' $a$ ' over party ' $b$,' information subsystem features of party ' $b$ ' including perspectives of its development, and the signatures level of the AF objectives and troops activities. One of the variants showing the conflict development state in the form of state space trajectory, taking into account the initial conflict state, is shown in Fig. 1.

The conflict development dynamics is employed in various forms and different ways of confrontation. In general, verbal models of conflict development can be represented in the following way.

One of the parties, using the pre-mission intelligence (collected during peacetime), prepares and delivers a massive strike at the AF objectives, including the reconnaissance facilities of the other part. The efficiency of the strike will depend on the following:

- authenticity of the intelligence collected during peace-time;

- reconnaissance mobility potential of the opposing force, dealing with the strike, and its antijamming capabilities;

- combat reaction time of the attacker (time elapsed from the reconnaissance mission completion to the strike delivery).

In this case the control of strike delivery efficiency can be carried out through the use of General Reconnaissance facilities. The strike delivery management of this type is performed according to the principle of surprise attack at the soft targets. The effectiveness of protection depends on military intelligence support and the facilities which provide protection as a result of the reconnaissance information. Besides, the defending part will strive to deliver a retaliatory blow or a launch under attack. The damage effect of these attacks is determined by the quantity of the secured means of destruction, survivability of C4I system, as well as availability and accuracy of the intelligence concerned with the opposing force at the strike delivery time. A special point in the confrontation is the intention of the defending party to deliver a launch under attack, i.e. before the PGM impact on the attacked AF objectives. However, the damage incidence to the attacked party can be significant, and in case of the massive strike it substantially increases. To decrease the damage incidence inflicted on the defending party, two ways can be considered:

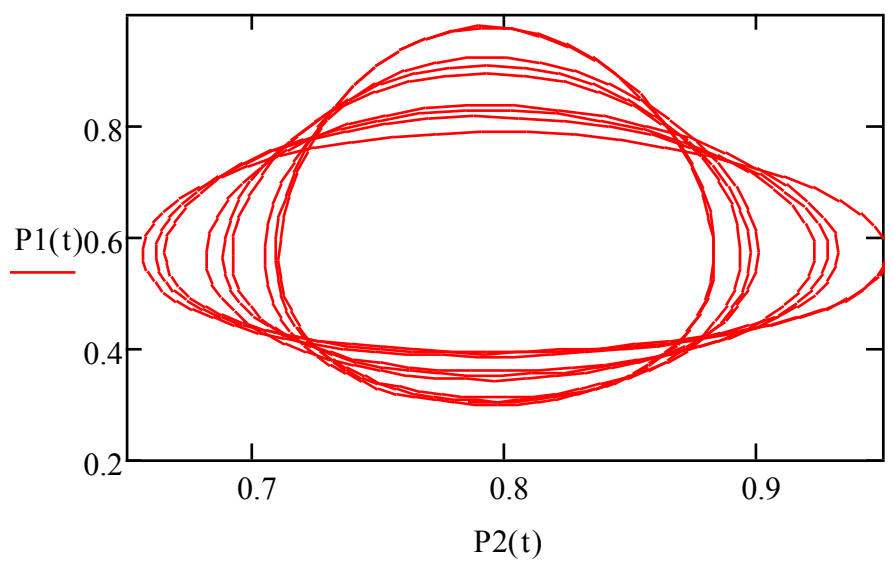

Fig. 1. State space trajectory of opposing forces conflict 
- providing high-performance system of integrated AF defense which eliminates the possibility of significant damage to the defending party;

- delivery of launch under attack by the defending party, which prevents strike delivery before their combat employment by the opposing force.

These ways are not mutually exclusive and can be realized in full to ensure the AF objectives' defense in various military-political situations, where the efficiency of the above considered suggestions may vary.

The climax of information confrontation is when one of the opposing parties is ready to deliver a massive strike at the AF of the other party, which, in its turn, is ready to deliver a launch under attack. Furthermore, each party is ready to defend friendly AF from the massive strike, and through the reconnaissance subsystems seeks to detect the most advantageous time to enable a massive strike delivery. The high tension of confrontation is determined by far-reaching implications both in case of delay and being too early before the opposing party starts their activity. A delay in the actions causes the opposing part to overcome the complex protection system (its suppression or destruction) and deliver highly-efficient massive strike. Being too early may result in that not all objects subject to the attack can be detected and destroyed at the first massive strike. In addition, the considerable period of time in stealing a march may cause the disclosure of control and destruction facilities which allows for more precise massive strike delivery by the opposing part.

Negative consequences may also include the change of the attitude to the attacking party: because of the too early actions it can move to the aggressor status (according to the international norms), which causes aggravation of the international situation and mobilization of international community to deter the 'aggressor.' Such a situation can be arranged purposely, inducing the opposing party for the activity which as a whole is aggressive in its nature.

Thus, the conducted military-system analysis of the reference state of opposing forces formed during information and fire conflicts allows for the following conclusions.

The change in modern forms and methods of combat gives rise to the primary role of information superiority over the opposing force. One of basic elements for achieving such superiority is the information support realized through the corresponding reconnaissance system.

Reconnaissance systems efficiency, in turn, is realized by reducing military signatures in all spheres of general and operational reconnaissance to the state which makes opponent's effective reconnaissance application impossible in zones, located beyond the reach of friendly reconnaissance systems.

The estimation of goals achievement success in the information-fire conflict can be acquired by means of methodical framework and information conflict models, which deal with opposing parties as strictly antagonistic. The resulting estimations depend on initial conditions that emphasize the necessity of continuous information support of the Armed Forces accomplishing different missions during peace-time.

\section{References}

[1] Воробьев И. // Военная мысль, 2005, 3, 2 [Vorobiev, I. // Military thought, 2005, 3, 2. (in Russian)]

$$
-339-
$$


[2] А.С. Рукшин Военное искусство в локальных войнах и вооруженных конфликтах: военно-исторический труд. М. Воениздат, 2009, 764 с. [A. S. Rukshin Military art in local wars and armed conflict: military-historical work. M. Voenizdat, 2009, p. 764 (in Russian)]

[3] А.И.Смирнов, И.Н.Кохтюлина Глобальная безопасность и «Мягкая сила 2.0»: вызовы и возможности для России. М.: ВНИИгеосистем, 2012, 252 с. [A. I. Smirnov, I. N. Kohtumine Global security and "Soft power 2.0": challenges and opportunities for Russia. - M.: Vniigeosystem, 2012, 252 p . (in Russian)]

[4] Лифанов Ю.С., Саблин В.Н., Салтан М.И. Направления развития зарубежных средств наблюдения за полем боя. М.: Радиотехника, 2004, 64 с. . [Lifanov, S. Yu., Sablin V. N., Saltan M. I. Directions of development of foreign means of observing the battlefield. M.: Radiotehnika, 2004, 64 p. (in Russian)]

[5] Верба В.С. Обнаружение наземных объектов. Радиолокационные системы обнаружения и наведения воздушного базирования. М.: Радиотехника, 2007, 360c. [Verba V. S. Detection of ground objects. Radar system detection and homing air-based. M.: Radiotehnika, 2007, 360p. (in Russian)]

[6] Ю.Л. Козираикий Модели информационного конфликта средств поиска и обнаружения. М.: Радиотехника, 2013, 232 с. [Y. L. Koziratskiy The Model information of the conflict of means of search and discovery. M.: Radiotehnika, 2013, 232 p. (in Russian)]

[7] А.А. Бобриков Оценка эффективности огневого поражения ударами ракет и огнем артиллерии /. СПб.: Галея Принт, 2006, 417 с. [А. A. Bobrikov Evaluation of the efficiency of fire defeat an onslaught of missile and artillery fire, SPb.: Galeya Print, 2006, 417 p. (in Russian)]

[8] Демин В.П., Куприянов А.И., Сахаров А.В. Радиоэлектронная разведка и радиомаскировка. М.: МАИ, 1997, 156 с. [Demin, V. P., Kupriyanov A. I. Sakharov A.V. Electronic reconnaissance and radioactive. Moscow: MAI, 1997, 156 p. (in Russian)]

[9] Варламов А.В., Кисиленко Г.А., Хорев А.А., Федоринов А.Н. Технические средства видовой разведки. М.: РBCH, 1997, 327 с. [A. V. Varlamov, G. A. Kisilenko, A. A. Horev, Fedorina A. N. Technical means imagery intelligence. Moscow: RVSN, 1997, 327 p. (in Russian)] 